\title{
APPROACHES TO THE QUANTIFICATION OF THE HUMAN CAPITAL EFFICIENCY IN ENTERPRISES
}

\begin{abstract}
Human capital is one of the enterprise inputs. There are people who are the bearers of new knowledge, ideas, experiences and skills; they contribute to their own personal growth as well as to increasing the performance and competitiveness of the whole enterprise. Human capital management helps enterprises to achieve enterprise goals just by using the human capital efficiently. For the assessment of the results achieved and directing further development it is important to know how to measure the efficiency. The aim of the article is: based on the study of special and scientific foreign literature to identify and compare the different theoretical approaches to the measurement of the efficient use of human capital for possible implementation in enterprise practice.
\end{abstract}

Keywords: Human capital, value, efficiency, measurement, management.

\section{Introduction}

Organizational performance refers to an organization's results, including operating results (productivity, quality, efficiency, etc.), market results (sales, market share, customer satisfaction, etc.) and financial results (costs, revenues, profits, etc.). There is considerable evidence that achieving expected organizational performance is determined by achieving desired employee performance that refers to employees' working results and behaviour, determined by employees' abilities (knowledge and skills to perform agreed work) and motivation (willingness to perform agreed work), which enable an organization to achieve expected goals [1].

The prerequisite for increasing the performance and competitiveness of the enterprise is, in particular, the efficient use of production inputs. The efficiency is a qualitative criterion, which involves such ways of the use of production factors, which compare the inputs and the effects achieved. Economic theory introduces, and there are united methodologies for the quantification and assessment of the efficiency of non-current assets, current assets and work in enterprise practice. However, this does not apply to human capital.

Human capital is relatively a young production factor, and as it is closely related, and in some respects, it has similar features as a production factor of work, economic analyses and research works do not often make an explicit distinction among them.
However, a different angle on the working activity of a man and currently increasing appreciation of the importance of quality human capital also require new, different types of indicators, which would express better the impact and mainly the benefits of the variable [2].

Qualitative nature of the human capital is difficult and many times does not allow easy quantification, an attempt to derive the partial relations and contexts, the modification of existing indicators, identification of new parameters as well as the proposal for a new methodology of new statistical surveys can contribute to a better understanding of the total impact of human capital on the company and the enterprise as well.

The aim of the article is to identify and compare the different theoretical approaches to the measurement of the effective use of human capital for possible implementation in enterprise practice.

\section{Human capital and Efficiency}

Efficiency is generally defined as the relationship between the outputs achieved and the inputs used. The efficiency of human capital can be calculated analogically as a percentage of the value of enterprise output and the value of the input (the human capital). However, when choosing output and input, there must be chosen such variables, which relate to each other and are crucial to the administration of the enterprise performance [3].

\footnotetext{
* ${ }^{1}$ Alzbeta Kucharcikova, ${ }^{2}$ Lubica Konusikova, ${ }^{1}$ Emese Tokarcikova

${ }^{1}$ Department of Macro and Microeconomics, Faculty of Management Science and Informatics, University of Zilina, Slovakia

${ }^{2}$ Silesian university in Opava, School of Business Administration in Karvina, Czech Republic

E-mail: Alzbeta.Kucharcikova@fri.uniza.sk
} 
Therefore, the efficiency represents the ability of the work value to create a product. Human capital is effective only if the product is greater than its value. It is being understood that the higher is the difference between the value and the product, the higher is the efficiency. From a macroeconomic point of view, the efficiency of human capital can be expressed as a percentage of the lifelong product $\mathrm{HC}\left(\mathrm{Y}_{\mathrm{LK}}\right)$ and its value $\left(\mathrm{H}_{\mathrm{LK}}\right)$.

$\mathrm{E}_{\mathrm{LK}}=\frac{\mathrm{Y}_{\mathrm{LK}}}{\mathrm{H}_{\mathrm{LK}}}$

When starting working, human capital has a certain value (e.g., school graduate), which, however, constantly improves and its value rises in the context of the working process. This is due to the acquisition of new skills, knowledge, and habits. The indicator of the value of human capital is therefore not stable, but on the other hand, a dynamic variable, which constantly develops and changes by the influence of circumstances [4].

The value of human capital differs in each individual, as it is developed by the age and conditions the bearer has available. It is gradually increased from the birth until the old age, when it begins to decline. The value of human capital is increased, particularly through new experiences and knowledge acquired in education or other forms of development of human capabilities and creativity [5].

Calculating and monitoring the efficient use of human capital, it is therefore necessary to quantify the output produced by the human capital and the size / value of the human capital.

The output, when measuring the efficient of human capital, may be the degree of fulfilment of the enterprise goal (e.g.: increasing the customer satisfaction, increasing sales, reducing the error rate, shortening the time dealing with complaints, etc.), the quantification of the enterprise savings, the number of registered patents and inventions per one employee or worker of the development department, the volume of performance per one employee, etc.

Considering the measurement of the size of human capital, there are several known approaches, but no single methodology, as in other enterprise inputs, has been accepted so far. The problem is the quantification of the different components of human capital, i.e. knowledge, abilities, skills, motivation, talent, etc.

According to Mazouch and Fischer [6] there are three factors acting on human capital and its value. The initial factors are genetically inherited, inborn abilities of an individual. These can subsequently be developed by further activity of the environment and education. As a consequence of family, social, other factors of environment and education there are acquired and developed skills and knowledge. An important discovery that we must not forget is that the various components of human capital will affect each other. As the individual properties may affect the acquirement of the knowledge or the development of skills, the development of properties and skills depends largely on the environment in which the individual is born.

\section{Indicators of the efficient use of human capital}

The use of human capital metrics is an important part of the human capital management (HCM). If management knows how to properly determine the value of human capital it has available in the enterprise, it is important to find whether it is used effectively. If not, it is essential that enterprise management identifies problems and sets measures, which would ultimately lead to the improvement and enhancement of individual enterprise processes.

Quantifying the size of the value of human capital and its efficiency is very difficult, but in the selection and construction of whether direct or indirect (auxiliary) indicators in this area, it is important that the metrics should be linked to the key performance indicators of the organisation.

\section{Conceptual model}

Conceptual model points out to the interconnection of human capital and the overall performance of the organisation (Fig. 1). This approach puts the emphasis on the strengthening of human capital, which leads to the increase of performance of individual employees and ultimately it has a positive effect on the overall improvement of organisation performance.

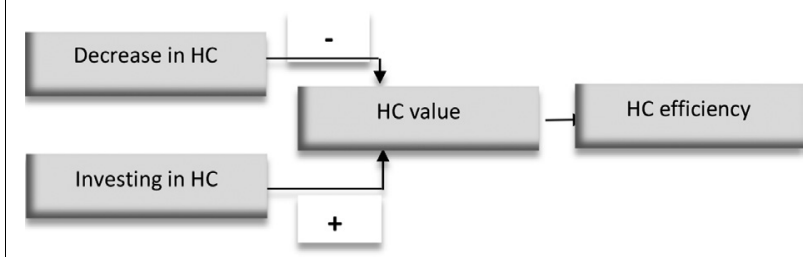

Fig. 1 Conceptual model for measuring the HC efficiency Source: [7]

The structure of conceptual model involves a link of relations among the investments in human capital, its decrease, value, total efficiency and their measurement. The results of the measurements referred to four key areas in the enterprise can then be compared with other companies (benchmarking) [7].

Investment in human capital represents expenses the organisation invests to ensure training, education, development of knowledge and skills of its workers. The investment, together with the decrease, affects the value of human capital in the enterprise, and consequently its efficiency. Investments have a positive effect and contribute to increasing the human capital efficiency and, ultimately, lead to increasing the overall performance of the 
enterprise. It may have financial, but also non-financial forms (Fig. 2). Financial performance includes productivity, market share, enterprise profitability, while non-financial performance includes customer satisfaction, innovation, and improvement of workflow and the development of workers' skills [8].

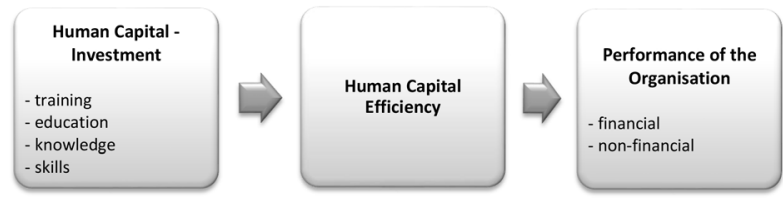

Fig. 2 A link of conceptual model with investments in HC, HC efficiency and performance of the organisation, (source: [8])

Human capital efficiency represents a dependent component within the conceptual model. Income factor is the basic measure of human capital efficiency that is calculated as a proportion of total income and total number of employees in the enterprise, while the factor of costs, profit and total return on investment to $\mathrm{HC}$ can be used as the other measures.

Decrease in human capital that may be caused by the departure of workers, has a negative impact on the HCM. The decrease of workers can be given, for example, by the percentage of individuals who have left the enterprise voluntarily, or the percentage of involuntary loss of HC (Fig. 1). For the calculation of the value of human capital, an enterprise may use measurements expressing the factor of income compensated, i.e. what percentage of the income from the sale goes to employees, or the factor of costs compensated, i.e. what percentage of operating expenses goes to employees [7].

\section{Human Capital Efficiency - HCE}

According to Andrienssen [9], the human capital efficiency (HCE) may be expressed as a percentage of the added value (VA) and human capital (HC).

$\mathrm{HCE}=\frac{\mathrm{VA}}{\mathrm{HC}}=\frac{\text { Operating profit }+\mathrm{HC}}{\mathrm{HC}}$

\section{The metrics of human capital efficiency according to 4 factors}

One of the most commonly used measurements of the efficient use of human capital is based on the study of the authors Bontis and Fitz-enz [7]. The HC measurement is realised on the basis of four essential metrics, which are income factor, cost factor, profit factor and HC ROI. The main goal of any organisation is to increase income, or profit per one employee. Increasing human capital and its efficiency bring higher financial results per one employee. Its development is largely influenced just by raising the level of education together with the total satisfaction of the employees. For this reason, human capital has also a direct impact on the profitability of investment in the ROI enterprise. The FTE indicator in the metrics is the full-time equivalent (FTE), which includes full and partial employment contracts and volunteers. It shows how much time has been spent on generating income (Table 1).

Metrics of human capital efficiency according to 4 factors Table 1

\begin{tabular}{|l|c|}
\hline Indicator & Formula / metric \\
\hline $\begin{array}{l}\text { COST } \\
\text { FACTOR }\end{array}$ & $\frac{\text { operating costs }}{\text { FTE }}$ \\
\hline $\begin{array}{l}\text { INCOME } \\
\text { FACTOR }\end{array}$ & $\frac{\text { income }}{\text { FTE }}$ \\
\hline $\begin{array}{l}\text { PROFIT } \\
\text { FACTOR }\end{array}$ & $\frac{\text { income }- \text { operational costs }}{\text { FTE }}$ \\
\hline HC ROI & income - (operational costs - wages and benefits) \\
\hline
\end{tabular}

Source: [7]

\section{Human Economic Value Added - HEVA}

The measurement of the economic value added of human capital (HEVA) is the possible way used to measure human capital efficiency. The indicator is based on the economic value added (EVA) from the Stern Stewart. The purpose of the calculation is to find whether the activities of the management have added value for the enterprise. The indicator EVA is also used in the measurement of human capital. In this case, it is completed in divisor of item FTE (full-time equivalent, which includes full-time, partial work load, or volunteers). It is one of the fundamental metrics designed to measure human productivity, that is, how much time people spend creating profits for the enterprise [10].

HEVA $=\frac{(\text { NOPAT }- \text { WACC.C })}{\text { FTE }}$

where:
NOPAT net operating profit,
WACC weighted average cost of capital,
C the size of the capital invested.

\section{Human Capital Cost Factor - HCCF}

Human capital cost factor (HCCF) is another indicator taking into account the costs associated with wages and the calculation of the value. The basic principles of human capital are ranked into four categories. It is salary and costs for benefits for 
employees, volunteer wages, costs associated with the fluctuations and absence. Salary represents a real wage paid to the employees of the enterprise. Considering the benefits, there are calculated all benefits provided by the company for employees of the enterprise. The costs associated with fluctuations themselves involve several factors, such as severance payments, or costs the enterprise must spend on a new employee or his/her total training and enlistment in the collective of the enterprise [10].

$\mathrm{HCCF}=$ salary + benefit costs + volunteer wages + costs associated with fluctuation and absence

\section{Human Capital Value Added - HCVA}

HCVA is an indicator of human capital value added, which is the sum of all operating costs, where the costs of employees' work and other associated benefits are not taken into account. The result is an operating profit per employee working full-time. In the majority of enterprises, the employees are just the most important asset. Therefore, human capital is the main prerequisite for success in the future. On the other hand, they are often associated with large costs, or in other words, investments. Due to this fact, it is very important to know what value added they can bring for the enterprise. Using this indicator, we can find the average profitability per employee of the enterprise [11].

HCMV $=\frac{\text { sales }-(\text { cost of wages and benefits })}{\text { FTE }}$

\section{Human Capital Market Value - HCMV}

Human capital market value (HCMV) is an interesting indicator for the calculation of human capital efficiency. It expresses the relationship between the value of the enterprise and its value based on the accounting. In terms of some literature indicator is understood as a metric for measuring the $\mathrm{HC}$ value. In the context of a given indicator, there are also included, except $\mathrm{HC}$, various forms of intellectual capital. Due to the fact that there is mainly taken into account the value of intangible assets, in addition to human capital, there may be also included capability of processes, public awareness about the brand, or setting up of marketing processes. The indicator is more interesting for economists, analysts, but it is not very useful for managers. It reflects the market value premium per employee [10].

HCMV $=\frac{\text { enterprise market value }- \text { accounting value }}{\text { FTE }}$

All of these metrics which are designed to calculate the efficiency of human capital differ from each other in the approach to the calculation of the upper part of the formula. The denominator of these metrics have always found the number of partial and full-time jobs. However, this cannot clearly define the value of human capital in a particular firm. For this reason, it is necessary to pay more attention to determining the value of human capital. In business, it is a challenge for human resource managers to find various indirect indicators that are able to assess the size of human capital with regard to the sectorial focus of the company.

There are a number of consulting companies, which have extensive databases, monitor and evaluate a number of indicators in the field of human capital. Involvement, however, is worth the money and does not contain a thorough analysis aimed at identifying key indicators of human capital for a particular company, but only the evaluations based on the internal data provided and its comparison with other companies operating in the same industry [12].

\section{Principles of efficient management and measurement of human capital performance}

Efficient performance management and human capital require new perspectives and new competencies of line managers and HR professionals. Human capital management considers people the wealth or asset and not as a cost item, as it was regarded in the concept of human resources management or personnel management. However, in connection with the HC management, the application of metrics at any price and without the advanced concept, can ultimately be counterproductive for the enterprise.

Becker, Huselid, Ulrich [13] suggested six principles for measuring performance and efficiency of human capital. The use of these principles can transform human capital into major driving engines of financial performance of any enterprise:

- Focus on the strategic impact of human capital.

- Avoid the alchemy of human capital.

- Measure not only the level of human capital, but the relationships as well.

- Recognise the limitations of benchmarking.

- Do not start with the measurement.

- Think in terms of the "architecture" of human capital.

In this dynamic era it is very important for enterprises to identify strategies how in current high-velocity environment sustaining its competitive advantages [14]. Globalization, increasing independence and complexity, new technologies and climate change create new challenges for enterprises [15]. The investments to the human capital present the most profitable form of improving the situation in firms from the long-term and perspective point of view [16]. To increase performance and efficiency of human capital contributes introduction of the motivation program. Employers should focus on the process of motivation through factors based on interpersonal relationships and job security, too. We can assume that motivation through 
these factors will increase and employees will consider them more important [17]. Also we can say that in spite of employee heterogeneity in terms of age, seniority and level of completed education it is possible to create a unified motivational programme for the analysed enterprise that will suit all employees regardless of their age, seniority or education. Its main items are following factors: basic salary, job security, good work team, further financial reward and fair appraisal system in different order according to preferences of specific group of employees [18]. Results indicated that innovation competency positively influences organisational performance and organisational knowledge management influences innovation competency positively, too [19].

\section{Conclusion}

For the efficient functioning of the enterprise on the open market, it is necessary to increase the efficient use of the enterprise production inputs. In terms of human capital management, it means to search for the connection of enterprise performance with the use of specific knowledge, skills and abilities of its employees in order to increase competitiveness. There were identified and compared some of the metrics published in the field of human capital efficiency. However, for the implementation in practice of a specific enterprise, it is necessary to adapt these indicators to the specific conditions of enterprise, in the context of enterprise strategy. With respect to the fact that there are no united metrics adopted and used in this area, it is precisely the role of the HR managers to take advantage of their knowledge, creativity, analytical thinking and design such metrics of efficient use of human capital for the conditions of their enterprises to be able to direct the care of human capital towards increasing individual performance and the performance and competitiveness of the whole enterprise. We can see a great space for further research in this area.

\section{Acknowledgement}

This article was created as part of application of project: Innovation and internationalization of Education - Instrument to increase the quality of the University of Zilina in the European educational area. Modern Education for the Knowledge Society ITMS 26110230079/Project is funded by EU; Grant VEGA 1/0421/13 and grant VEGA 1/0526/13.

\section{References}

[1] SIKYR, M.: Best Practice Approach to Human Resource Management. The $9^{\text {th }}$ Intern. Days of Statistics and Economics, Prague, September, 2015, pp. 1405-1414, ISBN 978-80-87990-06.

[2] KUCHARCIKOVA, A., BABISOVA, R., BACINSKA, K., GRIVALSKA, I., KRISTANOVA, J., VADOVIC, T.: The Human Capital Efficiency in Enterprises. Scientific J., Faculty of Social and Economic Relations: Alexander Dubcek University of Trencin, vol. 13, No. 1, 2015, pp. 58-65, ISSN 1336-3727.

[3] DURISOVA, M., JACKOVA, A., HOLKOVA, B.: Business Economics. EDIS: University of Zilina, 2015, 247 p., ISBN 978-80-5540997-9.

[4] BARANIK, M., HABANIK, J.: Introduction to Macroeconomics, IRIS, Bratislava, 2002, p. 232, ISBN 80-89018-45-9.

[5] VOJTOVIC, S.: The Conception of Personnel Management Human Resources. Grada Publishing: Prague, 2012, p. 192.

[6] MAZOUCH, P., FISCHER, J. Human Capital - Measurement, Context, Forecasts. Praha: C. H. Beck, 2011, 116 p., ISBN 978-807400-380-6.

[7] BONTIS, N., FITZ-ENZ, J. Intellectual Capital ROI: A Causal Map of Human Capital Antecedents and Consequents. J. of Intellectual Capital, vol. 3, No. 3, 2002, pp. 223-247.

[8] MARIMUTHU, M., AROKIASAMY, L., ISMAIL, M.: Human Capital Development and its Impact on Firm Performance: Evidence from Developmental Economics. The J. of Intern. Social Research, vol. 2/8, summer 2009, pp. 265-272.

[9] ANDRIENSSEN, D.: Making Sense of Intellectual Capital, Taylor \& Francis Ltd: New York, 2011, ISBN: 978-0-7506-7774-5, p. 456.

[10] FITZ-ENZ, J.: The ROI of Human Capital: Measuring the Economic Value of Employee. Amacom: New York, 2009, 310 p., ISBN 978-0-8144-1332-6.

[11] MARR. B.: Key Performance Indicators (KPI): The 75 Measures Every Manager Needs to Know. FT Press: Harlow, 2012,376 p., ISBN 978-027375011.

[12] KUCHARCIKOVA, A., DURISOVA, M.: Human Capital Efficiency in Transport Enterprise. Proc. of 18 ${ }^{\text {th }}$ Intern. Conference. Transport Means, 2014, pp. 23-24,10.20104, Kaunas University of Technology, pp. 239-243. ISSN 2351-4604. 
[13] BECKER, B. E., HUSELID, M. A., ULRICH, D.: Six Key Principles for Measuring Human Capital Performance in Your Organization. State University of New York: Buffalo, 2002, pp. 1-16.

[14] CIRJEVSKIS, A.: Sustainability in Higher Education: Discourse on Dynamic Capabilities of Privately Run Higher Educational Institutions (HEI) in Latvia. J. of Security and Sustainability Issues, vol. 5, No. 1, 2015, pp. 111-112, ISSN $2029-7071$.

[15] KLUCKA, J.: Renewable Resources and Critical Infrastructure - the Framework. Advanced Material Research, vol. 1001, 2014, pp.475-483, ISSN 1662-8985.

[16] KONUSIKOVA, L., KUCHARCIKOVA, A.: Approaches to Active Labour Market Policy in the Slovak Republic, Czech Republic and Finland. Communications - Scientific Letters of the University of Zilina, vol. 17, No 2, 2015, pp. 73-79, ISSN 1335-4205.

[17] HITKA, M., STACHOVA, K., BALAZOVA, Z., STACHO, Z.: Differences in Employee Motivation at Slovak Primary Schools in Rural and Urban Areas. Intern. Education Studies, vol. 8, No. 5, 2015, pp. 33-42, ISSN 1913-9020 E-ISSN 1913-9039.

[18] HITKA, M., BALAZOVA, Z.: The Impact of Age, Education and Seniority on Motivation of Employees. Business: Theory and Practice, 16(1), 2015, pp. 113-120 ISSN 1648-0627/eISSN 1822-4202, doi:10.3846/btp.2015.433.

[19] JUNGES, F. M., GONCALO, C. R., GARRIDO, I. L., FIATES, G. G. S.: Knowledge Management, Innovation Competency and Organisational Performance: A Study of Knowledge-intensive Organisations in the IT Industry. Intern. J. of Innovation and Learning, vol. 18, No. 2, pp. 198-221, ISSN 1471-8197/eISSN 1741-8089. 